\title{
Against Commodification: The University, Cognitive Capi- talism and Emergent Technologies
}

\author{
Richard Hall* and Bernd Stahl**
}

\author{
* Directorate of Library and Learning Services, De Montfort University, Leicester, UK, \\ rhall1@dmu.ac.uk, http://www.richard-hall.org \\ ** Centre for Computing and Social Responsibility, De Montfort University, Leicester, UK, \\ bstahl@dmu.ac.uk, http://www.cse.dmu.ac.uk/ bstahl/
}

\begin{abstract}
This paper investigates how four specific emergent technologies, namely affective computing, augmented reality, cloud-based systems, and human machine symbiosis, demonstrate how technological innovation nurtured inside the University is commodified and fetishised under cognitive capitalism or immaterial labour, and how it thereby further enables capital to reproduce itself across the social factory. Marx's critique of technologies, through their connection to nature, production, social relations and mental conceptions, and in direct relation to the labour process, demonstrates how capital utilizes emergent technologies to incorporate labour further into its self-valorisation process as labour-power. The University life-world that includes research and development is a critical domain in which to site Marx's structural technological critique, and it is argued that this enables a critique of the public development and deployment of these technologies to reveal them as a fetishised force of production, in order to re-politicize activity between students, teachers and the public.
\end{abstract}

Keywords: University, Emergent Technology, Academic Activism, Commodification, Cognitive Capitalism

\section{Introduction}

Emergent technologies, represented below in the four manifestations of affective computing, augmented reality, cloud-based systems, and human machine symbiosis, serve as examples of how technological innovation is commodified and fetishised within the University, and how it thereby enables capital to reproduce itself. Marx $(2004,493)$ understood and described this in terms of technology's place inside a historical totality: "Technology discloses man's mode of dealing with Nature, the process of production by which he sustains his life, and thereby also lays bare the mode of formation of his social relations, and of the mental conceptions that flow from them". Thus, emergent technologies that are produced at the limits of "man's modes" of recasting and reforming social relationships offer a critical insight into how capital co-opts research and development inside the University, in order to restructure higher education for value formation and accumulation.

The argument outlined herewith will develop this idea of co-option through an analysis of how technological developments are underpinned by commodification and fetishisation. A focus on emergent technologies enables an exploration of the possible ways in which technological innovation may affect power struggles and resistance in the academy, in particular where these are still being embedded in the academic practices of the University. However, they demonstrate the potential to change significantly both the ways in which education is conceived and delivered, and through which its institutions reproduce capitalist social relationships, in order to re-inscribe the history of labour-in-capitalism (Postone 1996). Thus at the core of the argument lies an engagement with the mechanisms through which these emergent technologies reproduce hierarchical power inside the University. In analysing the interstices between commodity fetishism, emergent technologies and higher education, the relationships between emerging technologies, academic activism, and the possibilities for student/worker protests inside and beyond the academy will be addressed.

The domain of the University is important here as a site of cognitive or knowledge capital. Under modes of cognitive capitalism (Dyer-Witheford 1999, Virno 2004, Williams 2012), these social relationships are constructed out of the compression and enclosure of time and space themselveswrought by technologically-transformed capital (Lebowitz 2003, Marx 2004, Postone 2009). This process of transforming the University into an active site of struggle over the value produced by cognitive capitalism is accelerated through the commodification of emergent technologies and their subsequent fetishisation. This process amplifies how capital manoeuvres for power inside the academy, and promotes an instrumentalism of academic practice that is related through immaterial 
labour and class struggles to critiques of academic activism and cybernetic control of knowledge production (Holloway 2002, Tiqqun 2001, Virno 2004).

One result is that an engagement with autonomous Marxism's critique of power relations can enable an argument for the development of emergent technologies as spaces for dissent. Here the co-operative conquest of power might be developed as a step towards the abolition of power relations (Holloway 2002, Dyer-Witheford 2004), in order to re-inscribe a different set of possibilities upon the world, and to critique how our technologically-enabled global webs of social relations contribute to the dehumanisation of people, where they are treated as means in a production/consumption-process rather than as ends in themselves able to contribute to a common wealth. At issue is whether students and teachers are able to recapture the production and distribution of emergent technologies, in order to dissolve the symbolic power of the University into the actual, existing reality of protest and negation. Moreover, in Harvey's $(2010,46)$ terms, can a critique of emergent technologies enable those who work in higher education "to find an alternative value-form that will work in terms of the social reproduction of society in a different image"?

\section{A Note on Technology}

The historical development of technology inside capitalism has served as a means for reproducing biopower (Feenberg 1999, Foucault 1977, Noble 1998, Weber 1969), and for systematising the control of labour through socio-technical routines, procedures and cultures (Postone 1996). This enculturation is a key point for the Ethical Issues of Emerging ICT Applications (ETICA) project's scoping of the interplay between ethics and technology. The argument detailed below builds on some of the findings of this project. The project team argue that a technology

"is a high level system that affects the way humans interact with the world. This means that one technology in most cases can comprise numerous artefacts and be applied in many different situations. It needs to be associated with a vision that embodies specific views of humans and their role in the world" (Ikonen et al. 2010, 3-4).

This role in the world is underpinned by a range of socio-technical characteristics. Thus, in an analysis of ambient technologies, these characteristics are revealed by the actors engaged with them as embeddedness, interconnectedness, invisibility, adaptivity, personalisation, and pervasiveness. As a result, the ETICA project defined a socio-technical view of the world, in which human enterprise, or labour, requires and desires technological support that is increasingly seamlessly connected, and which is increasingly adaptive, through the systemic integration of artifacts such as sensors, networks, algorithms and grids.

The emerging and everyday reality of adaptive technologies shaping and redefining the relationship between humanity, nature or the world and power emerges as a central thread inside a Marxist analysis of the relationships between machines and humanity. Marx $(1993,594)$ argued that technologies in the form of machines "are the products of human industry, natural materials transformed into instruments of the human domination of Nature, or of its activity in Nature... they are the materialised power of knowledge". This materialised power then reflects the relationships that exist between those who use those technologies to create, repurpose and reproduce society, and both those who innovate around those specific technologies and those who use them in their labour. For Feenberg $(1999,83)$ this means that "technology is a site of social struggle", through which hegemonic positions are developed, legitimated, reproduced and challenged, and he argues $(1999,87)$ for "[a] critical theory of technology [that] can uncover that horizon, demystify the illusion of technical necessity, and expose the relativity of the prevailing technical choices".

This view of technology as a critical site of struggle reflects the amplified alienation of labour inside the social factory, achieved through the symbiosis of human and machine (Negri 1989, Tronti 1973). As humanity is entwined and embedded with technological appendages, the possibilities for cybernetic control and the further alienation of subjectivity become more apparent (Tiqqun 2001). Harvey (1990) argues that such objectification is a function of the incorporation of the flesh and blood of humanity inside the machines of capital as one response of neoliberalism to the economic and political crises of the 1970s. In this view, capital actively sought new strategies that "put a premium on 'smart' and innovative entrepreneurialism" (Harvey 1990, 157). Such entrepreneurialism was in part realised in emergent technologies that incorporate humanity inside the reality of fixed 
capital. This fusion of dead and living labour from which new forms of value can be extracted, is a critical way in which the circulation costs of capital can be reduced (Marx 2006). For Hardt and Negri $(2000,406)$ this is a deeply political antagonism for "machines and technologies are not neutral and independent entities. They are biopolitical tools deployed in specific regimes of production, which facilitate certain practices and prohibit others".

Here it is the productive power of socio-technical systems and the creation of cybernetic systems that enable humanity or its life-world to become increasingly machinic, so that humanity's everyday existence is incorporated inside the means of re-production of capital (Habermas 1987, Hardt and Negri 2000, Marx 2004, Tiqqun 2001). In Marxian terms this further objectifies social relationships as commodities from which value can be extracted through, for instance, the monitoring and harvesting of personal data, the enclosure and control of spaces or applications of consumption, the use of venture capitalism to support specific social networks, and the technological augmentation and capture of affectivity. This real subsumption of everyday activity then ensures that for the individual

"the creative power of his labour establishes itself as the power of capital, as an alien power confronting him... Thus all the progress of civilisation, or in other words every increase in the powers of social production... in the productive powers of labour itself - such as results from science, inventions, divisions and combinations of labour, improved means of communication, creation of the world market, machinery etc., enriches not the worker, but rather capital; hence only magnifies again the power dominating over labour.. the objective power standing over labour" (Marx 1993, 307).

Thus, technologies are deployed by capital as revolutionary forces that enable it to destroy "all the barriers which hem in the development of the forces of production, the expansion of needs, the allsided development of production, and the exploitation and exchange of natural and mental forces" (Marx 1993, 409). This exploitation is constantly seeking to overcome the barriers that result from physical limitations, and increasingly rests on the fusion of the human as social being with technology, in order to create new commodities and forms of fetishisation. The University is one sociotechnical space in which capital develops this process of overcoming.

\section{On the Commodification of Technologies, Immateriality and the University}

The period of global austerity politics signaled by the collapse of Lehman Brothers in 2008 has witnessed a neoliberal backlash against state-subsidized public assets, as a form of economic shock therapy (Klein 2007). In the United Kingdom, this process has led to the incorporation of higher education inside the market logic of capitalism, with a concomitant transfer of the idea of higher education as a public good to become one where it is produced as an individual good to be serviced through private debt on a North American model (Collini 2012, Bailey and Freedman 2011, Williams 2012). This subsumption of the life of the University inside the market reflects the systemic logic of capital, which aims to totalise itself (Hardt and Negri 2000). As Meiksins Wood $(1997,1)$ noted

we're living in a moment when, for the first time, capitalism has become a truly universal system.... Capitalism is universal also in the sense that its logic - the logic of accumulation, commodification, profit-maximisation, competition - has penetrated almost every aspect of human life and nature itself.

One of the ramifications of this process for academics and students is the commodification of their scholarly work, in terms of courses, technologies, knowledges and cultural assets (Ball 2012, Canaan and Shumar 2008, Newfield 2012, Williams 2012). Labour inside the University is increasingly: driven by efficiency; underpinned by the dictates of key information sets and impact measures, public/private partnerships, knowledge transfer and external income generation; and disciplined by the logic that if a producer of educational goods is inefficient it will suffer in the market (Cullerne-Browne 2012, McGettigan 2012). Thus, higher education has become a site of marketisation in which knowledge-work as the labour of an individual academic is being brought into direct competition with that of other academics, across societies and inside new partnerships between state assets and private corporations. 
Competition between individual academics and these new associations of which they form a part then forms a way of structuring socially the allocation/abundance of relevant, academic labour (Marx 2004). The incorporation of academic work inside the market catalyses the subsequent creation of academic use-values that can be exchanged, and scholarship that can be commodified. The nature of exchange, and the attempt to extract surplus value from a co-opted academic process, means that hierarchical power relations developed inside universities are re-produced as the relation between those things that can actually be exchanged. As a result, academic labour is directly subsumed under this drive to extract surplus value (Clark 1994, Marx 2004).

Knowledge work inside the University is particularly valuable as a result of the amount of socially-necessary labour-time embedded in its products. Marx highlighted that the magnitude of the value of labour, determined by the labour-time socially necessary to produce a specific commodity, is defined as "the labour-time required to produce any use-value under the conditions of production normal for a given society and with the average degree of skill and intensity of labour prevalent in that society" (Marx 2004, 129). Inside higher education, the specialisation of the work and the skilllevels required to innovate promise high rates of surplus value extraction, especially where technological research and development catalyses efficiencies in production and a reduced circulation time for specific capitals. This specialisation and the promise of increased rates of relative surplus value extraction fuels the employability agendas of government educational departments for whom the skills developed at University are framed increasingly by the needs of the labour market (Bailey and Freedman 2011, Ball 2012), which itself forms a central mechanism for regulating academic labour (Marx 2006).

As technologies inside capitalism are used to deliver systemic efficiency and further valorise value, it becomes difficult to sustain a positivist argument for the emancipatory potential of enhanced technological skills. The logic of technological innovation and deployment is for productivity gains or outsourcing, or for workplace monitoring and surveillance alongside labour management and stratification, or to catalyse the creation of value by opening up/harnessing new markets (Lebowitz 2003, Marx 2004). In the short-term, technological innovation gives capital a high marginal productivity underpinned by and underpinning high levels of demand from both public and private sectors. However, over time "moral depreciation" affects the gains made by technological innovation:

\begin{abstract}
"in addition to the material wear and tear, a machine also undergoes, what we may call a moral depreciation. It loses exchange-value, either by machines of the same sort being produced cheaper than it, or by better machines entering into competition with it. In both cases, be the machine ever so young and full of life, its value is no longer determined by the labour actually materialised in it, but by the labour-time requisite to reproduce either it or the better machine. It has, therefore, lost value more or less. The shorter the period taken to reproduce its total value, the less is the danger of moral depreciation; and the longer the working-day, the shorter is that period. When machinery is first introduced into an industry, new methods of reproducing it more cheaply follow blow upon blow, and so do improvements, that not only affect individual parts and details of the machine, but its entire build. It is, therefore, in the early days of the life of machinery that this special incentive to the prolongation of the working-day makes itself felt most acutely" (Marx 2004, 528).
\end{abstract}

As a result, the drive under the treadmill logic of competition becomes to deliver constant innovation across a whole socio-technical system, in order to maintain or increase the rate of extraction of relative surplus value, and to tear down the barriers of under-consumption. This has ramifications for academic labour as Newfield $(2010,13)$ highlights, with an increasing proletarianisation of scholarly work under three types of labour. The first type relates to "commodity skills", which are "readily obtained" and whose possessors are interchangeable, for instance, back-office or helpdesk workers. The second type incorporates those with "leveraged skills", which require advanced education and which offer clear added-value to the University, and yet which are possessed by labour in many universities, for instance, computer programmers or network administrators. The third type includes those with "proprietary skills", defined as "the company-specific talents around which an organization builds a business". University management cultivate and commodify only those with the skills to enhance propriety knowledge, from which rents or profits can be extracted.

The first two types of labour noted above can be proletarianised or outsourced because of the low levels of socially-necessary labour time embedded in the value of their work. However, as pro- 
prietary skills are enclosed the competitive nature of marketised academic labour ensures that such work becomes increasingly precarious (Bonefeld 2010, Neilson and Rossiter 2008). This is because the socially necessary character of the labour-power expended in producing a particular commodity or innovation or technology is diminished over-time and this reduces its value in the market. As a result a persistent demand to innovate becomes essential inside the system. Thus, it is around the holders and management of these proprietary or creative skills, which can be exchanged, where academic work that is congealed in the form of emergent technologies tends to become fetishised in its social form as value (Marx 1993).

Fetishisation describes how, in a commodity producing society, the relationships that exist amongst producers, mediated socially in the market, take on the form of a "social relation between the products of labour" (Marx 2004, 164). This means that the exchange value of a specific commodity, which is in reality an expression of socially-necessary labour time, appears to be an inherent property of the commodity, as revealed in its market price. In part this is because commodity producing labour does not appear to be directly social as commodities are produced by independent individuals. As a result, labour only appears to be socially-necessary in the process of exchange, rather than in the processes of production and this underpins a reality of alienation.

"[T]he result of the process of production and realization is, above all, the reproduction and new production of the relation of capital and labour itself, of capitalist and worker. This social relation, production relation, appears in fact as an even more important result of the process than its material results. And more particularly, within this process the worker produces himself as labour capacity, as well as the capital confronting him, while at the same time the capitalist produces himself as capital as well as the living labour capacity confronting him. Each reproduces itself, by reproducing its other, its negation. The capitalist produces labour as alien; labour produces the product as alien" (Marx 1993, 458).

The product or commodity has destroyed part of the living labour of the individual labourer and is alienated from her as a fetishised form of value through the process of exchange. Inside the University, where the struggle between labour and capital lies in the creation and commodification of cognitive capital, the notion of fetishism needs to be re-worked and re-analysed because the production and circulation processes are "immaterial" (Žižek 2009). For Feenberg (1999, viii) this is the reality of technological essentialism, where "technology reduces everything to functions and raw materials", with the result that individual emotions and affects, cultural cues and mores, and the construction of the relations between individuals "are themselves the very material of our everyday exploitation" (Žižek 2009, 139). From this process, two elements emerge as central in understanding how knowledge work or cognitive capital or the information society becomes fetishised. Firstly, capital finds mechanisms or technologies that enable it to enclose and commodify an increasingly fluid and identity-driven set of social relations, which can form the basis of further exchange (Virno 2001, Virno and Hardt 1996), catalysed by work inside the University and based on mutations of human subjectivity (Vercellone 2007). Secondly, capital commodifies and extracts value from everyday experiences and relationships, in order to reduce the unproductive circulation time of capital, and thereby increase the rate of profit and relative surplus value (Dyer-Witheford 1999; Marx 2006).

In this process of fetishisation, social relations are increasingly structured by technicallymediated organisations, like the University, which then re-inscribe anew socio-political hierarchies that are increasingly technological, coercive and exploitative (Foucault 1977). In part this alienates and separates individuals within a society through an exclusive division of labour (Lebowitz 2003; Marx 2004). Moreover, as Marx highlights (1993), the development of such technologies that subsume all of human life under capital's logic strengthens the idea that capitalist relations are natural and purely technical. However, this naturalisation process reveals the construction of knowledge through the reproduction of the general intellect, or knowledge as society's main productive force (Marx 1993). On the one hand, capital uses this process to subsume and alienate social relationships further as commodities, in particular through the control of communication and the repurposing of information (Dyer-Witheford 1999, Negri 1989). On the other hand, the reproduction of the general intellect as mass intellectuality becomes the actual foundation of subversion-throughpraxis (Neary and Hagyard 2010; Virno 2001).

In part these processes of the production, distribution and consumption of mass intellectuality are amplified by the extreme socialisation of web-based technologies and the ways in which emer- 
gent technologies are socialised. Therefore, the research and development of emergent technologies inside the University is a critical site of struggle through which a critical theory of sociotechnology and cognitive capitalism might be developed, and against which academic activism might be revealed. For Marx (2004) understanding socio-technical innovation and transformation was important because it highlighted the mechanics of the relationships between labour and capital.

By means of machinery, chemical processes and other methods, [capital] is continually transforming not only the technical basis of production but also the functions of the worker and the social combinations of the labour process. At the same time, it thereby also revolutionizes the division of labour within society, and incessantly throws masses of capital and of workers from one branch of production to another (Marx 2004, 617).

\section{Emergent Technologies and Cognitive Capitalism}

The influence of neoliberal ideology on higher education is being increasingly documented and analysed (Ball 2012, Canaan and Shumar 2008, McGettigan 2012, Newfield 2012, Williams 2012). There is a pervasive narrative that sees education as primarily concerned with developing students' employability, where science and technology form primary means of fostering economic growth, and where technologies underpin discourses related to value-for-money, commercial efficiency and business process re-engineering. These ideas can be found in high level policy documents such as the European Vision 2020 (European Commission (EC) 2010) or the Higher Education Funding Council for England's support for technology-enhanced learning (HEFCE 2012), and in the funding protocols for innovation programmes (EC 2012; Hall 2012). These protocols then shape and legitimise the spaces in which individual universities develop projects, mission statements or strategies, and they connect educational innovation to fiscal "realities".

This ideological positioning is reflected through funding strategies, which focus on innovation and research in the natural sciences and technology, with a concomitant diminishing flow of resources of social sciences and humanities. The use of technology within education amplifies this ideological turn, and further catalyses the commodification and fetishisation of educational practices and institutions (Dyer-Witheford and de Peuter 2009; Feenberg 1999), alongside their enclosure (Hall 2012). This thereby undermines education's moral legitimacy (Stahl 2006). At issue here then is to move this argument beyond the critique of established and embedded technologies inside the University, in order to analyse how emergent technologies might impact the forms and content of higher education and thereby enable capitalist social relations to be re-produced.

Critical in this process is the organisation, disciplining and exploitation of an increasingly immaterial workforce, through the use of emergent technologies that are inserted into the everyday activities and life-worlds of living human subjects (Dyer-Witheford 1999, Habermas 1987, Valtysson 2012), and which are incubated inside universities as centers of research and development. This is a relentless dynamic, centered on capitalism's constant revolutionizing of the means of production, in order that capital can drive "beyond every spatial barrier... [and the ability to enhance] the creation of the physical conditions of exchange - of the means of communication and transport - the annihilation of space by time - becomes an extraordinary necessity for it" (Marx 1993, 524). In reducing the time of production and circulation, technology is implicated in a totalizing re-production of social relations, which are in constant flux and motion (Postone 2009).

However, in this war on time and production/circulation costs, the fusion of human and machine forms a new front in the use of the machine as a weapon in the struggle of capital against labour. Research, development and implementation inside the University are sites of alienation, and therefore form spaces from which negation and dissent might spring. In developing this position, an analysis of four interconnected examples of emergent technologies enable a clearer understanding of likely future developments to emerge. In the following sub-sections the definition of emergent technologies is outlined alongside a justification for the choice of the four technologies that are discussed in more depth, with a view to understanding their role in future higher education. The technologies in question are: affective computing; virtual and augmented reality; cloud computing; and human-machine symbiosis. 


\subsection{Emergent Technologies}

The present discussion explores how emergent technologies that have been identified through horizon-scanning might be expected to influence higher education and contribute to the conceptual issues of fetishisation, commodification and immateriality. The basis on which to discuss such emergent technologies raises issues that are related to historical uncertainties in the future development of capitalism and the fundamental impossibility of predicting the nature and use of those technologies. Despite these future unknowns, humans have developed mechanisms for developing expectations and using these to make decisions that shape the future. One established mechanism in academia is the use of foresight research (Cuhls 2003), which does not claim to know the future but develops visions of possible futures that allow decision-makers to work towards possibilities that are deemed desirable. The argument developed herewith uses this logic and draws on existing research on future and emergent ICTs, which it then uses to explore the possible roles of such technologies in higher education.

The argument draws on the findings of the ETICA project (Ikonen et al. 2010) to clarify the roles that emergent technologies can play in higher education. The ETICA project was a Europeanfunded research project, which ran from 2009-11, and that could be characterised as a foresight project. It aimed to identify emerging technologies with a view to analyze their ethical consequences and thereby consider governance and policy implications. ETICA defined emergent technologies as those that are likely to change significantly the ways in which humans interact with the world in the near future of 10 to 15 years. These technologies are characterized by the fact that they are subject to intensive research and development, which allows a reasonable prediction of their future shape. It is important to note that whilst they are described as emergent, this does not affect their current status. Some of these emergent technologies are already established, for instance cloud computing, but they are described as emergent because there are significant research and development activities currently going on that are expected to change their shape and possible applications, and thus their socio-political consequences.

The ETICA project did not focus on applications of technology, either in higher education or in any other field, and the project did not apply a specifically Marxist viewpoint. The argument detailed herewith does not claim to represent ETICA in any way, nor does it reflect the position of the ETICA consortium. However, an analysis of the outcomes of first stage of the ETICA project enables the identification of webs of emerging technologies that are particularly pertinent for higher education. Engagement with four interconnected technologies serves as a point of departure for a demonstration of the commodification and fetishisation of the social relations and identities that emerge from inside the University and that underpin the development of mass intellectuality. These technologies are: affective computing; augmented reality; cloud-based systems; and human machine symbiosis.

These four technologies were chosen out of the 11 technologies identified by the ETICA project because they enable an interpretation of early technological adoption inside higher education, and their status as emergent technologies means that they are likely to become even more influential through the premium placed on high-technology (Gartner 2011). Thus, they lend themselves to an analysis of how the University is impacted by emergent technology. They represent a spectrum of technologies that cover the issues discussed here and which then exemplify the re-production of socio-technical systems inside the University, as well as the potential to resist prevailing ideological developments. However, each of the four interacts with at least one of the others, and this offers the possibility that combinations of innovation might impact the relationships that exist between capital and labour inside higher education. Each of the four technologies are discussed in a separate sub-section which defines them, and which then discusses expected uses in higher education, and how utility relates to questions of ideology, fetishisation, commodification and immateriality. Pathways towards resistance, exemplified by these technologies, are then suggested.

\subsection{Affective Computing}

The technology: affective computing, sometimes also called emotional computing, aims to develop artefacts that can perceive, express and model human emotions. Interest in the computational aspects of affects or emotions developed inside research laboratories in the last decade of the 20th century, paralleled by the neoliberal focus on enterprise technologies that could be deployed as innovations in the social factory. A critical development was the increased capabilities of 
computers to model emotions (Cowie 2005), and to work for embedding emotionality into sociotechnical systems that in turn enable capital to use cognition or immateriality to reproduce itself. Such re-production is witnessed in the widening of the definition of such technologies to include emotion-processing or human behavioral modeling.

Thus, this type of research underpins the creation of more responsive applications where human and computers interact, in order to harness the use of emotions in decision-making through data collection for profiling, and brain imaging tools and sensors for the detection of emotions. Whilst Robinson and el Kaliouby's (2009) research discusses a number of application areas related to social inclusion and modeling social cognition, it is clear that affective computing enables the commodification of social cognition. For instance, it is used: in modeling products related to the management of social-emotional intelligence by agents and robots (Tao and Tan 2005); in developing affective games that react to a player's emotional state and enabling the game to deliver content at the most appropriate moment (Sykes and Brown 2003); and generating the ability to communicate the affective state of a game player to third parties (Hudlicka 2009).

For capital, capturing and mining this type of activity is an important field of innovation and value extraction, because "data suggest that less than $10 \%$ of human life is completely unemotional. The rest involves emotion of some sort" (Cowie 2005). Thus, capturing emotionality or affect through technology focuses upon enhancing "the quality of human-computer communication and improving the intelligence of the computer" (Tao and Tan 2005, 981). As emotion pervades human interaction, sensitivity to emotions becomes fundamental to communicative action (Habermas 1987). As a result, affective computing influences the ways in which humans interact with the world as it is mediated through feelings and the physical changes associated with them, alongside shifts in perception, judgments, and actions.

Educational application: the ability to understand and react to the emotional states of users is envisaged through innovations in types of e-teaching related to games-based learning and virtual world simulations, where sensing the learner's mood allows the customization of learning content and presentation (Porto Interactive Center 2012, xDelia 2012). Driven by research and development in affective computing, cognitive and behavioral psychology are further commodified inside capital, in-part through the partnerships between universities and commerce, as affective computing drives the assumption that human emotions are capable of being measured, recognised, classified, produced and valorised (Massachusetts Institute of Technology (MIT) Media Lab 2012). An important aspect of this emergent technology is that there is a direct link between emotions and external actions like consumption.

Similarly an emotional awareness would allow better responses from teachers who are then able to monitor their own and students' emotional states, in order to gather mutual feedback on the success of teaching sessions. Thus, the MIT Media Lab (2012) focuses upon "computing that relates to, arises from, or deliberately influences emotion or other affective phenomena". The growing focus on learning analytics as a means of monitoring and surveillance learning outcomes, in order to commodify them, also connects cognitive and emotional practices and outcomes (Educause 2012), especially where they are connected to the on-going fetishisation of learning delivery through mobile devices (Blackboard 2012).

The potentially positive outcomes of the use of affective computing in higher education, in particular in work-based and placement learning, and related to simulations, can be contrasted with less beneficial ones, relating to increased manipulation and control. Personal behaviours and characteristics can be more easily inscribed inside teaching programmes by rewarding particular reactions to managed interventions. This is exacerbated by the fact that the use of such technologies in education would likely be designed by private corporations for profit or through rents emerging from application-based interventions. These interventions are likely to be translated into marketised solutions, which in-turn enable students to be more successfully oriented towards employability, rather than a critical questioning of the discourses around the political role of the University.

Resistance: a critical space for resistance related to affective computing is through rehumanisation and the co-operative development of solutions to problems related to gaming, simulations or work-based learning, and the outright refusal to commodify virtual interactions. In fact, affective computing offers a clear space for analysing socio-technical systems that are ethically problematic, as users are able to discern the possibility of being manipulated. Moreover, there is good reason to believe that where scholars resist the appearance of emotions in educational machinery, in-part because such emotions appear to be false in the sense that they are fundamentally different from human emotions, they are able to develop an ethical digital literacy. In particular this 
relies upon the engagement of mutual networks of scholarly critique, in order to connect real-world emotionality to shared problem-solving. The hope is that this will overcome the threat of individuated, false or augmented affects, which separate users from each other and enable cognitive capitalism to maintain its power relationships inside the University, for example through the sousveillance (Ganascia 2010) of teachers by students or of management by staff.

\subsection{Virtual and Augmented Reality}

The technology: virtual or augmented reality is closely related to affective computing, It developed from Heilig's (1962) Sensorama Simulator that was designed to mitigate against the risks that came with hazardous jobs by simulating the environments in which capital needed labour to be trained. The history of the development of virtual and augmented reality deeply connects innovation inside the University with commercial enterprise. Thus, applications like Lanier's VPL DataGlove demonstrated that these technologies could be extended beyond head-worn displays to include handheld and LCD displays, and into smart-phones whose applications extend the marketisation of everyday experience, through the enclosure of content and concomitant subscription or rental. This content is then further commodified as virtual information is projected onto the augmented objects or as augmented information is projected onto the real life contexts (Zhou et al 2008).

Advanced computer hardware enables virtual and augmented reality applications to become more immersive and integrated into daily life. Thus, the technology is extendable into the manufacture and repair of complex machinery, in reducing the costs of maintaining fixed labour, alongside its potential to annotate objects and environments, and further fetishises the user's experiences of her life-world and her very identity. Capital uses these techniques to influence the behaviour, interpersonal communication and cognition of labour, and also to enhance the colonisation and enclosure of virtual space, meaning that virtual identities, like avatars, are individuated and commodified beyond the social relationships from which they spring. Thus, virtual objects convey information that enables the real subsumption of labour in its performance of real-world tasks. By supplementing an everyday reality with virtual objects or data the immaterial labourer is able to perceive the environment more comprehensively than with her own senses. Consequently the process of immersion enables the enhancement of labour's perception of and interaction with the real world by capturing and harnessing multiple sensorial channels (Cline 2005). This enables capital to reproduce itself in new forms and through the production of new services that move beyond the barriers of under-consumption.

Educational applications: the use of virtual and augmented reality technologies in higher education is well advanced, and focused on training, discover-based learning, modelling, gaming and extending virtual resources. It has historical links with defense and military training, and with extending opportunities for marketing (Hamilton 2011), and mobile learning (Joint Information Systems Committee (JISC) 2012). For instance, Second Life (Dyer-Witheford and de Peuter 2009) serves as a platform to provide material and interactions inside scholarly communities, and for experimenting with simulations, in-part as a form of play. Universities have used this platform to provide specific training on topics that require more than a textual interface, for instance in the management of schizophrenia or in health sciences where views of bodies or organs may be required, as well as in interacting with remote students through the construction of virtual campuses. While Second Life may be the most prominent example of virtual environments, there is a broader move towards such technologies in higher education (Human Interface Technology Laboratory New Zealand (HIT Lab NZ) 2012), and to some degree Learning Management Systems like Blackboard increasingly seek to incorporate aspects of augmentation and immersion into their virtual environments.

Resistance: augmentation enables the creation of spaces from which rents can be extracted by private corporations operating inside education through in-world or application-based innovation. This demonstrates the co-opted inter-relationships between emerging technologies, the labour-incapitalism and higher education (Dyer-Witheford and de Peuter 2009). Virtualisation catalyses significant discussion inside universities and from higher education policy-makers about whether external providers should host educational activities and extract rents as a form of accumulation. This is partly driven by practical considerations such as intellectual property and the security of teaching material in outsourced environments. However, scholarly resistance focuses upon technical and usability issues, alongside the acceptability of engaging in the further enclosure of virtualised space through augmentation technologies (Wake and Stahl 2010). At issue in the educational resistance 
to augmented technologies is the ways in which scholars are actively encouraged to produce and share open curricula and artifacts in ways that reveal humanising engagements that do not form new commodities, but help maintain a diversity of expertise across communities. Thus, in these mutual spaces, the relevance of marginal developments like application-based, locative and augmented reality services might be questioned through consensus, and related to social need and issues of privacy and identity.

\subsection{Cloud Computing}

The technology: increasingly the innovative services addressed by affective computing or virtual and augmented reality, are being managed through cloud computing, which promises to deliver computing resources to different locations through globalised circulation networks. It originated with Licklider's work on ARPANET (Ikonen et al. 2010). Alongside the generation of value for the military, its development was predicated upon its value as a public utility like water or electricity. This became increasingly possible via the growth in bandwidth in the 1990s. As a direct result, its development was able to facilitate remote working, and the separation and surveillance of proletarianised work at a distance from any formal, Taylorised work setting, enabling capital to distribute available commodity and leveraged skills amongst low-wage societies through outsourcing (Newfield 2010). The evolution of cloud computing through phases of grid and utility computing, application service provision, and Software as a Service (Dikaiakos et al. 2009), enables the dynamics of cognitive labour to pervade the social factory and thereby amplify immateriality on a global scale (Hardt and Negri 2000, Virno 2004).

In particular, cloud computing enables capital both to extract value from social networks and personal interconnections through the corporate control of systems, networks and data, and to reduce the circulation costs of productive capital through scalable and elastic IT-enabled capabilities that are delivered as a service from low wage circuits into those spaces from where high value can be extracted (Marx 2006). As enterprises seek to consume their IT services in the most costeffective way, interest has grown in drawing a broad range of services, for example, computational power, storage and business applications, from the "cloud" rather than from on-premises equipment. This outsourced approach is focused on reducing the costs of distribution of commodities and labour.

Where cloud services are used to store very personal data, such as photos and videos, data mining and tagging are enmeshed with capitalist accumulation through rental costs, and targeted marketing. In some cases this enables smart consumption, for instance through the data-driven connection between hardware like RFID tags and smart-phones, localisation services, and cloudbased services like customer relationship management systems and payment service providers (The Think-Trust project 2010). It also enables the commodification of data related to medical records between business and insurance partners (Andriole and Khorasani 2010), thereby supporting the further incorporation of bio-power into healthcare. Ease of use of cloud services is emphasized with very fast, optimized connections and enforced terms of service or agreements through which users give away ownership of personal data (Fuchs 2010). The interconnections generated by shared data in these networks are very dynamic and enable the consumers of these services to produce and consume a nomadic lifestyle that is bound less by space than by time. In fact, the permanent immateriality of these services forms an attempt by capital to annihilate space by time.

Educational applications: cloud computing is a technology that is already used in higher education, in particular to share services, like email and back-end information management, and for research processes or data storage (JISC 2011). It is particularly widespread with regards to social networks and other social media, which tend to be in profit-oriented and which then further reify and objectify human relationships. This is realised in the discourses around words like "follower" and "friend". Inside Universities, attempts are also being made to commodify and sell the idea of cloud computing in terms of green IT or sustainability, despite the lack of evidence that the cloud is "greener", and industry has wrapped itself around this concept as a space for further service-led innovation (Hall and Winn 2011).

A related question is how cloud computing can affect the way in which higher education is structured and organised, and in particular how Universities redesign their teaching design and delivery around the cloud (Das 2012) and services like library provision (Sanchati and Kulkarni 2011). In the United Kingdom there is a debate about the use of technology to decrease the price of education and cloud computing is perceived to be one means by which services can be shared and thus 
costs can be reduced. This is purely oriented towards the financial cost of education through labour costs, and redesigning the labour market around commodified services (JISC 2011), and does not consider the ways in which pedagogic considerations impact technological deployment.

Resistance: cloud computing highlights the complex entanglements of technology, the social relationships that are revealed in organisational structures, and politics. On the one hand one can see examples of resistance to the extraction of rents and value from the implementation of cloud technologies that are directed at business process re-engineering. This is a form of statesubsidized privatization, and highlights concerns about the continuation and provision of services to students through outsourcing and sharing. This has concomitant data and privacy issues, as well as opening-up educational data for mining by transnational venture capitalists. Such transnational networks also enable governments to use the logic of homeland security to monitor data (Walden 2011).

However, social media also allow the circumvention of control and thereby offer new avenues for subversive collaboration against and resistance to managerial agendas. These uses of cloud computing lead to a blurring of boundaries and higher education institutions which are driven by financial interests and subsequently find it increasingly difficult to legitimise the boundaries between inside and outside the University. This is a problem for capital because its structures cannot control the activities of their employees and students in networks beyond the University, and these can be co-opted to open-up cracks in intellectual property and the production of social relationships for other, mutual interests. The implementation of cloud technologies thereby contain the seeds of resistance towards the very enclosing motives that promote it.

\subsection{Human-Machine Symbiosis}

The technology: the apogee of this attempt to reduce the costs associated with and emerging from the processes of exchange and the extraction of relative surplus value, and capital's desire to reduce socially-necessary labour time, is human-machine symbiosis or human augmentation. This is a technology in which the connections between affective and augmented technologies for the production of socially-defined, identity-driven commodities, and their development, monitoring and distribution through cloud-based tools are revealed. What is witnessed is the apotheosis of the fetishised form of the human as optimised labour-power; of the human as machine designed, augmented and alienated for the valorisation of value (Marx 1993).

Human-machine symbiosis was originally envisaged by Licklider $(1960,1)$ as a means by which more efficient co-operative action could be catalysed, through a "very close coupling" between human and machine, in order to increase the efficiency of "formulative thinking" and the control of "complex situations without inflexible dependence on predetermined programs". Licklider $(1960,1)$ hoped that "the symbiotic partnership will perform intellectual operations much more effectively than man alone can perform them". The premise was that human intellect could be augmented, and that as a result human beings would be able to perform tasks or labour that was beyond their ordinary physical limitations.

This approach led to the development of the mouse, to innovations in human-computer interaction, interactive computing, hypermedia, and video-conferencing, as mediums that enhance the efficiency and value of labour and reduce the circulation time of commodities (Ikonen et al. 2010). For Roy (2004) this meant that human-machine symbiosis could be understood as a technology that enhances and improves human potential where human capacities are restricted. He views the technological machine as an extension of the human, and such symbiosis emerges through wearable technologies, assistive technologies or neural implants (Ikonen et al. 2010).

Pace Marx (1993, 2004), this is one of the logical outcomes of capital's need to enforce cooperation in industrialised labour. This co-operation is dissolved into the fabric of society through: the development of personal consoles; the affective desires integrated into mobile and personal technologies; and the integration of machinery into the labourer's body as an extension of her labour-power. As Greef et al $(2007,1)$ argue in relation to augmented cognition, the aim is "the creation of adaptive human-machine collaboration that continually optimises performance of the human-machine system". This connects to Marx's (1993) view of the incorporation of labour inside the machinery of capitalist re-production. 


\begin{abstract}
"In machinery, objectified labour confronts living labour within the labour process itself as the power which rules it; a power which, as the appropriation of living labour, is the form of capital... The development of the means of labour into machinery is not an accidental moment of capital, but is rather the historical reshaping of the traditional, inherited means of labour into a form adequate to capital. The accumulation of knowledge and of skill, of the general productive forces of the social brain, is thus absorbed into capital, as opposed to labour, and hence appears as an attribute of capital" (Marx 1993, 694-695).
\end{abstract}

Human-machine symbiosis has now permeated society to an extent where technology appears as a fetish or veil, as the social brain appears to be a natural well-spring from capitalism's forces of production, constructed through emergent technologies. Thus, consumers have become dependent and reliant to a large extent on their personal technology, as it extends their role or identity in the social factory. This affects how labour is enabled to access information, to conduct business, and to communicate globally. However, although such symbiosis enables labour both to perform more complex computations and to reduce the costs of circulation of commodities as information or communication, the impact of moral degradation means that there is a persistent need to innovate.

Educational applications: possible applications relate to the provision of immediate and personalised feedback, as is seen in the medical work being carried out by the Human Machine Symbiosis Lab (MIT Media Lab 2012), which is designing, developing and evaluating new human machine interfaces that can be applied in haptic user interfaces related to the sense of touch. The lab aims to incorporate psychophysics, biomechanics and neurology in its development of smart and effective haptic interfaces and devices. Elsewhere, the MIT 10x program (2012) continually evaluates a cross-section of applications including aspects of memory, in order to enhance and expand human cognitive abilities. This focuses upon the radical re-structuring of the practices that underpin knowledge work both inside the University and through knowledge exchange into the social factory. Such symbiosis demonstrates a constant striving to commodify and re-produce human experience beyond the limits of human capabilities, as they are organised inside capitalism.

This augmentation of cognitive processing power underpins innovation in brain-machine interfaces, an emerging neuro-technology that translates brain activity into command signals for external devices. Research on these interfaces began in the 1970s at the University of California Los Angeles, with the establishment of a direct communication pathway between the brain and specific devices to be controlled. Whilst these technologies are mainly being developed for medical reasons (Berger 2007, Gasson and Warwick 2007) they also enable different forms of immaterial labour to be imagined inside the University, and as a direct result everyday experience is co-opted for the extraction of surplus value by corporations. This is seen in Human-Systems Integration for Optimal Decision Making, which augments labour in dynamic and complex environments like air traffic control and nurse training (Ikonen et al. 2010). Not only does research inside the University catalyse these innovations in immateriality, but those same University contexts provide work-based spaces in which they can be trialled and then embedded across society.

Thus, there is a focus inside the range of higher education contexts on the amplification of human-systems integration, in order to consider socio-technical issues related to personnel, training, system safety, and health hazards, in the design of the symbiotic technologies that a targeted audience will use. The Cognitive and Organisational Systems Engineering project (COSE 2012) is modelling human-systems integration to support optimal decision-making in a range of environments. This demonstrates how research that is generated inside the University enables integrated processes and tools to be developed and tested, in order that they revolutionise capitalist work and enable the re-production of capitalist social relations in the spaces beyond higher education. Thus, whilst these projects initially support people's cognitive work-based learning in health and air traffic management environments, the specific intention is to extend this immaterial work to other domains, through the integration of learning and training, people, technologies and the environments in which they work.

Resistance: human-machine symbiosis is a technology that carries the possibility of radical resistance to the incorporation of humanity inside the means of re-production on capitalist social relations, in particular through its impact on what human beings perceive as natural. This is amplified as close relationships between humans and technology are depicted as problematic and undesirable, in particular where a process of dehumanisation is uncovered as labour-power is continually optimised through upgrades. This is a refusal to accept humanity as machine designed, augmented and alienated for the valorisation of value. These uses of ICT are therefore be likely to encounter 
dissent inside higher education environments where one of the traditional aims is that of the development of autonomous individuals, rather than commodified individuality, an aim which is contradicted in the redevelopment of the technology itself.

\subsection{Summary: Emergent Technologies in Higher Education}

The innovations located in these four emergent technologies enable cognitive labourers to transcend physical barriers through virtual reality, and to consume their educational life-world in new ways. As those experiences are produced and commodified both globally and yet on an individual level, capital is able to capture and harness everyday experiences as commodities for rent, value extraction and profit (Clark 1994, Marx 2004), and for the subsequent re-production of itself through the development of proprietary skills. The very fact of capital's enclosure of the human body inside its machinery of exploitation is catalysed by research inside the University. However, it is also played out in: the deployment of marketised and cloud-based learning environments and educational services; the application of virtualisation and augmentation to education as a means of maintaining hegemonies; in work-based learning and placement experiences; and through the insertion of emergent machinery directly into the life-world of labour. This means that labour's very educational life-world is a site of surplus value creation and extraction, and accumulation through commodification and rent. As Meiksins-Wood (1997) identified, there is no outside of this system of alienation.

However, for Postone (1996) it is the historic role of labour-in-capitalism that contains revolutionary potential, precisely because its increasing exploitation, alienation and dehumanising mechanisation is persistently revealed in its everyday practices. As education becomes a core site for the re-production of hegemonic discourses and power relationships, this revelation of commodification that is amplified through technological innovation precedes reflexivity and praxis from inside the University. The possibility remains that labour will realise the increasing proletarianisation of its educational practices. Thus, it is possible to sketch and support a flowering of dissent based on the autonomous utilisation of those same emergent hardware, software and networks that are used to immiserate (Coleman 2012, Dyer-Witheford 1999, Newfield 2010). At issue here is how the production of emerging technologies inside the University might affect academic labour as a form of activism.

\section{For Exodus and the Courage of Academic Activism}

Holloway (2002) argues that we deceive ourselves if we believe that the structures which exist in order to reproduce capitalist social relations can be used as a means to overcome its alienating organisation of work. Whilst he makes this point for the structure of the democratic state as a symbol of failed revolutionary hope, his point might equally be made about the University.

"In reality, what the state [University] does is limited and shaped by the fact that it exists as just one node in a web of social relations. Crucially, this web of social relations centres on the way in which work is organised. The fact that work is organised on a capitalist basis means that what the state [University] does and can do is limited and shaped by the need to maintain the system of capitalist organisation of which it is a part" (Holloway 2002, 6).

Thus, any institution's room for manoeuvre is constricted by transnational global capital, and in particular by the compression and enclosure of time and space wrought by technologicallytransformed, finance capital. In this view, working to take control of an institution crushes the transformatory intent of those who would fight against capitalism, because this transformation is always about limited manoeuvring for power. In Virno's (n.d.) terms this is based on "weak thought", or a political philosophy that "was developed by philosophers with theories that offer an ideology of the defeat [of the labour movement by neoliberalism] after the end of the "70s". Thus, educational values are predicated instrumentally on the tenets espoused by liberal democracy as it is revealed inside capitalism, tied to tropes of equality or liberty, or on often ill-defined practices/qualities like respect or openness. Even inside the University it becomes difficult to imagine a different form of social life beyond the realities of capitalist work.

In this way the fetishisation of emergent technologies risks reinforcing hegemonies, so that they are seen as revolutionary only in terms of how they generate individual, user-generated outcomes, 
rather than in describing new forms of value. In this view, they re-produce a set of universal, transhistorical norms, through which it is simply not acceptable to argue for other forms of value or organisation beyond those imposed by democratic capitalism. Moreover, it no longer becomes possible to address the structural dominance of educational elites within capitalism, or the limited, procedural definition of the value of education and educational innovation inside capitalism. Important here are the mechanisms by which innovation flowing to/from the University supports the ways in which neoliberal capitalism intentionally designs, promotes and manages forms of democracy and governance that complement its material objectives (Harvey 2010). This is achieved, inpart, through the implementation of ideological control inside the socio-technical institutions and cultures of civil society, which in-turn make it impossible to step beyond the controlling logic of the rights of consumers.

This is not to say that oppositional forms that are against the University, and which utilise open and emergent technologies do not exist (EduFactory 2012, Hall 2011, OpenDemocracy 2012, FThe Sociological Imagination 2012, Occupy Wiki 2012). The counter-hegemonic practices of occupation are increasingly being seen as educational, and are enabling the re-imagining of socio-technical systems and forms of life, through general assemblies, militant research strategies and activity that is deliberative and conducted in public. In fact, it is from the activities of these global movements, arising from indignation, that a critique of the development of emergent technologies inside the University might be situated, in order to identify opportunities for dissent, negation and pushing back against the alienating rhetoric of capitalist work (Holloway 2010). This critique emerges from two strands: firstly, in being against pedagogies of consumption that define the uptake of emergent technologies through the commodification of engagement and activity; secondly, from the recognition that those technologies help to critique the reality and history of labour-in-capitalism.

In some cases these radical education projects are working politically to re-define issues of power and are an attempt to re-inscribe higher education as higher learning dissolved into the fabric of society. In most cases they see the institution of the school or the university as symbolically vital to a societal transformation. They form a process of re-imagination that risks fetishisation or reification of radical education, but which offers a glimpse of a different process that shines a light on the University as one node in a global web of social relations. This also focuses upon rethinking in public the role of academics in society, facilitated through emergent technologies and where the use of these technologies for production-in-public is the central organising theme. One focus is on overcoming individuation through association and embedding resources in target communities with an academic, co-operative consideration of the issues involved (Downes 2012).

Thus, where a critique of everyday scholarly activities, related to higher learning inside and beyond the academy, is folded into the logic of capital's production of these technologies, they become a networked space within which negation, dissent and revolt can emerge (Holloway 2002). Here, globally-connected, human-machine symbiosis might become especially important in overcoming the totalising logic of capitalism where it enables the mutual, co-operative conquest of power as a step towards the abolition of power relations. Critical here is the revelation of the dehumanisation of people as means in a production/consumption-process, for example in the mining of emotions enabled by affective computing or in the virtualisation of educational life, rather than as individuals able to contribute to a common wealth. Thus, the use of cloud-based, emergent technologies offers the possibility to connect a global politics of refusal through socio-technological systems. This demands the invocation of a world of disjuncture, disunity, and discontinuity, where academic labour inside capitalism becomes riskier as the repetitive, precarious nature of its alienation and dehumanisation is revealed.

The connection of higher education and society through emergent technologies is important in defining spaces for dissent and pushing-back that are technologically-enabled, because the University remains a symbol of those places where mass intellectuality can be consumed, produced and more importantly contributed to by all. Thus, the revelation of shared experiences of alienation inside the social factory, using emerging technologies that heighten the sensation of oppression and enable them to be shared, offers a possibility that new sites of opposition and critique can be created. In amplifying this process, scholarly practices inside the University offer sites for courageous action against states of exception (Agambe 2005) that enclose how and where and why people assemble, associate and organise. However, academics inside the University have little room for manoeuvre in resisting the enclosing logic of competition and in arguing for a socialised role for higher education, given the ideological, political drive towards, for instance, indentured study and debt, internationalisation, privatisation and outsourcing. As a result, the internal logic of 
the University is increasingly prescribed by the rule of money, which forecloses on the possibility of creating transformatory social relationships as against fetishised products and processes of valorisation.

The idea of exodus is important here, as a form of dissent, revolt or rebellion against capital's exploitation of the entirety of social life, as it is revealed through emergent technologies. This exploitation is witnessed in affective technologies through playbor in games-based industries (DyerWitheford and de Peuter 2009), and in the harvesting of cloud-based data for the the subsumption of identities for further accumulation by social networks (Winer 2011), or in the enclosure of the open web through augmentation applications that are designed for profit (Short 2011). Thus, the fetishisation of personalisation, of self-branding, of the emergent technologies through which individuals connect, risks the commodification of each and every action we take in the world. However, this enhanced, connected, semantic web of social relations also offers a crack through which the domination of capital might be opposed. As Illich $(1975,82)$ argues: "Only among convivially structured tools can people learn to use the new levels of power that modern technology can incorporate in them". Thus, the very automation or human-machine augmentation and symbiosis that capital demands and develops in order to discipline and control labour makes possible an exodus from the society of capitalist work through the radical redisposal of the surplus time that arises as an outcome of that automation, alongside the new ways in which different groups can interconnect in that surplus time (Virno 2004).

Academics then have an important role in amplifying the potentialities for an exodus away from the society of capitalist work. This is more than a series of atomised rearguard actions against capital's cybernetic command (Dyer-Witheford 1999). This role begins in negation or refusal of the starting point for cognitive labour. For Noble (1998), this meant arguing against the conversion of intellectual activity into intellectual capital and hence private property, catalysed through virtualisation that is itself driven by the commodification of research and teaching and the emergence of commercially-viable, proprietary products that can be marketised. The capitalist processes of deskilling and automation, fetishisation of products, and proletarianisation of labour are at the core of this process. Thus, by reconnecting the University life-world that includes research and development to Marx's deeper, structural technological critique, it is possible to legitimise the developmentin-public of emergent technologies, and their revelation as a fetishised force of production, as a repoliticised form of activity between students, teachers and public. Moreover, it becomes possible to use this legitimation to catalyse spaces of dissent or protest that underpin new workerist revolts (Coleman 2012, Mason 2012). The workerist nature of these protests is important because of the tendency of capital to subordinate and exploit proletarianised social labour, in order to sustain and enhance the more valuable, cognitive labour of those with proprietary skills (Newfield 2010, DyerWitheford 2004).

Thus, in the mass of protests that form a politics of events against austerity academics need to consider their participatory traditions and positions, and how they actively contribute to the dissolution of their expertise as a commodity, in order to support other socially-constructed forms of production. In the critique of knowledge production, revealed through the production/consumption of specific emergent technologies, the University can grow in excess of its symbolic role. As a result, students and teachers might reconsider how they engage with emergent technologies, in order to contribute to a re-formation of their webs of social interaction. How do students and teachers contribute to public dissent against domination and foreclosure? For Marx $(1992,2004)$, technology is a central strand in the revolutionary transformation of society. This transformation overthrows the capitalist value-form in the construction of an alternative value-structure, and an alternative valuesystem that does not have the specific character of that achieved under capitalism. Pace Marx scholars might consider how their work on and with emergent technologies dissolves the symbolic power of the University into the actual, existing reality of protest, in order to engage with this process of transformation beyond mere commodification.

\section{References}

Agamben, Giorgio. 2005. State of Exception. Chicago: University of Chicago Press.

Andriole, Katherine P., and Ramin Khorasani. 2010. Cloud Computing: What Is It and Could It Be Useful? Journal of the American College of Radiology 7 (4): 252-254.

Azuma, Ronald T., Baillot, Yohan, Behringer, Reinhold, Feiner, Steven, Julier, Simon and Blair Maclntyre. 2001. Recent Advances in Augmented Reality. IEEE Computer Graphics and Applications. Accessed April 1, 2012. 
http://www.cs.unc.edu/ azuma/cga2001.pdf

Bailey, Michael, and Des Freedman. 2011. The Assault on Universities: A Manifesto of Resistance. London: Pluto Press. Ball. Stephen J. 2012. Global Education Inc. New Policy Networks and The Neo-Liberal Imaginary. London: Routledge.

Berger, Theodore W. 2007. Report on International Assessment of Research and Development in Brain-Computer Interfaces. Accessed April 1, 2012. http://www.wtec.org/bci/BCl-finalreport-100ct2007-lowres.pdf

Blackboard Inc. 2012. Blackboard Mobile. Accessed April 1, 2012. http://www.blackboard.com/Platforms/Mobile/Overview.aspx

Bonefeld, Werner. 2010. What is the alternative? Shift Magazine, 11. Accessed April 1, 2012. http://shiftmag.co.uk/?p=400 Canaan, Joyce. E, and Wesley Shumar, eds. 2008. Structure and Agency in the Neoliberal University, London: Routledge. Clarke, Simon. 1994. Marx's Theory of crisis. Basingstoke: Macmillan Press.

Cline, Mychilo S. 2005. Power, Madness, and immortality: The future of virtual reality. University Village Press.

COSE. 2012. COSE Project. Accessed April 1, 2012. http://www.nicta.com.au/research/projects/cose

Collini, Stefan. 2012. What Are Universities For? London: Penguin.

Colman, Gabriella. 2012. Our Weirdness is Free. Triple Canopy, 15. Accessed April 1, 2012. http://canopycanopycanopy.com/15/our_weirdness_is_free

Cowie, Roddy. 2005. What are people doing when they assign everyday emotion terms?. Psychological Inquiry 16 (1): 1148.

Cuhls, Kerstin. 2003. From forecasting to foresight processes - new participative foresight activities in Germany. Journal of Forecasting 22 (2-3): 93-111. Accessed April 1, 2012.

Cullerne-Brown, William. 2012. Research Blog. Accessed April 1, 2012. http://exquisitelife.researchresearch.com/exquisite_life/williamcullernebown.html

Das, Gaurav. 2012. 6 universities to teach cloud computing, mobile tech. Accessed April 1, 2012. http://articles.timesofindia.indiatimes.com/2012-02-08/guwahati/31037183_1_cloud-technology-manipur-universitycurriculum

Dikaiakos, Marios D., George Pallis, Dimitrios Katsaros, Penkaj Mehra, and Athena Vakali. 2009. Cloud Computing: Distributed Internet Computing for IT and Scientific Research. IEEE Internet Computing 13 (5): 10-13.

Downes, Stephen. 2012. Welcome to Change: Education, Learning, and Technology! Accessed April 1, 2012. http://change.mooc.ca/about.htm

Dyer-Witheford, Nick. 1999. Cyber-Marx: Cycles and Circuits of Struggle in High Technology Capitalism. Chicago, IL: University of Illinois Press.

Dyer-Witheford, Nick. 2004. Autonomist Marxism and the Information Society. Canberra: Treason Press. Accessed April 1, 2012. http://libcom.org/library/autonomist-marxism-information-society-nick-witheford.

Dyer-Witheford, Nick, and Greg de Peuter. 2009. Games of empire: global capitalism and video games. Minnesota: University of Minnesota Press.

EduFactory. 2012. Accessed April 1, 2012. http://www.edu-factory.org/wp/

EC. 2010. COM(2010) 2020: Europe 2020 - A strategy for smart, sustainable and inclusive growth. Accessed April 1, 2012. http://ec.europa.eu/eu2020/

EC. 2012. Research and Innovation: Framework Programme 7. Accessed April 1, 2012. http://ec.europa.eu/research/fp7/

Educause. 2012. Learning Analytics: 51 Resources. Accessed April 1, 2012. http://www.educause.edu/Resources/Browse/LearningAnalytics/39193

Greef de Tjerk. E., Arciszewski Henryk F.R., and Mark A. Neerincx. 2010. Adaptive Automation Based on an ObjectOriented Task Model: Implementation and Evaluation in a Realistic C2 Environment. Journal of Cognitive Engineering and Decision Making 4 (2): 152-182.

Feenberg, Andrew. 1999. Questioning Technology. London: Routledge.

Foucault, Michel. 1977. Discipline and Punish. New York: Pantheon.

Friedewald, Michael. 2005. The Continuous Construction of the Computer User: Visions and User Models in the History of Human-Computer Interaction. In Total Interaction: Theory and Practice of a New Paradigm, edited by Gerhard M.

Buurman, 26-41. Basel: Birkhäuser.

Fuchs, Christian. 2010. Labor in Informational Capitalism and on the Internet. The Information Society 26 (3): 179-196.

Ganascia, Jean-Gabriel. 2010. The generalized sousveillance society. Social science information 49 (3): 489-507.

Gartner. 2011. Gartner's 2011 Hype Cycle Special Report Evaluates the Maturity of 1,900 Technologies. Accessed April 1, 2012. http://www.gartner.com/it/page.jsp?id=1763814

Gasson, Mark, and Kevin Warwick, K. 2007. D12.1 Study On Emerging Aml Technologies. FIDIS - Future of Identity in the Information Society. Accessed April 1, 2012. http://www.fidis.net/resources/deliverables/hightechid/d122-study-onemerging-ami-technologies/doc/8/

Habermas, Jürgen. 1987. Lifeworld and System: A Critique of Functionalist Reason, volume 2 of The Theory of Communicative Action. Boston: Beacon Press.

Hall, Richard. 2011. Occupation: a place to deliberate the socio-history of re-production. In Roundhouse Journal: Reimagining the University 2: 54-63.

Hall. Richard. 2012. Educational Technology and the War on Public Education. Accessed April 1, 2012. http://www.richard- 
hall.org/2012/03/22/educational-technology-and-the-war-on-public-education/

Hall, Richard, and Joss Winn. 2011. Questioning Technology in the Development of a Resilient Higher Education. ELearning and Digital Media 8 (4): 343-356.

Hamilton, Karen E. 2011. Augmented Reality in Education. Accessed 14 March, 2012. http://wik.ed.uiuc.edu/index.php/Augmented_Reality_in_Education

Harvey, David. 1990. The Condition of Postmodernity: An Enquiry into the Origins of Cultural Change. Cambridge: Blackwell.

Harvey, David. 2010. A Companion to Marx's Capital. London: Verso.

HEFCE. 2012. Enhancing Learning and Teaching through the Use of Technology. Accessed April 1, 2012. http://www.hefce.ac.uk/learning/techlearn/

Heilig, Morton L. 1962. Sensorama Simulator. Accessed 14 March, 2012.

http://www.mortonheilig.com/SensoramaPatent.pdf

HIT Lab NZ. 2012. BuildAR. Accessed 14 March, 2012. http://www.buildar.co.nz/

Holloway, John. 2002. Change the World Without Taking Power. London: Pluto Press.

Hudlicka, Eva. 2009. Affective Game Engines: Motivation and Requirements. In Proceedings of the 4th International Conference on Foundations of Digital Games, 299-306. Orlando, Florida: ACM. doi:10.1145/1536513.1536565

Human Machine Symbiosis Lab. 2012. Accessed April 1, 2012. http://symbiosis.asu.edu/research hms.html

Ikonen, Veikko, Kanerva, Minni, Kouri, Panu, Stahl, Bernd Carsten \& Wakunuma, Kutoma. 2010. ETICA Project Deliverable D.1.2: Emerging Technologies Report. Accessed April 1, 2012.

http://ethics.ccsr.cse.dmu.ac.uk/etica/deliverables/D12Emergingtechnologiesreportfinal.pdf

Illich, Ivan. 1975. Tools for Conviviality, London: Fontana.

JISC. 2011. Cloud Computing Increasingly Attractive to Universities. Accessed April 1, 2012. http://www.jisc.ac.uk/news/stories/2011/05/cloud.aspx

JISC. 2012. Mobile Learning Infokit. Accessed April 1, 2012. https://mobilelearninginfokit.pbworks.com/w/page/41122430/Home

Klein, Naomi. 2007. The Shock Doctrine: The Rise of Disaster Capitalism. London: Penguin.

Lebowitz, Michael A. 2003. Beyond Capital: Marx's Political Economy of the Working Class. Basingstoke: Palgrave Macmillan.

Lepratti, Rafaello. 2006. Advanced Human-Machine System for Intelligent Manufaturing: Some Issues for Employing Ontologies for Natural Language Processing. Journal of Intelligent Manufacturing 17 (6): 653-66.

Licklider, Joseph C.R. 1960. Man-Computer Symbiosis. IRE Transactions on Human Factors in Electronics, HFE-1: 4-11. Accessed April 1, 2012. http://groups.csail.mit.edu/medg/people/psz/Licklider.html

Mason, Paul. 2012. Why It's Kicking Off Everywhere: The New Global Revolutions. London: Verso.

Marx, Karl. 1992. Capital, Volume 3: A Critique of Political Economy. London: Penguin

Marx, Karl. 1993. Grundrisse. Foundations of the Critique of Political Economy. London: Penguin.

Marx, Karl. 2004. Capital, Volume 1: A Critique of Political Economy. London: Penguin.

Marx, Karl. 2006. Capital, Volume 2: A Critique of Political Economy. London: Penguin.

McGettigan, Andrew M. 2012. Critical Education: All about the Arts, Humanities and Higher Education today. Accessed April 1, 2012. http://andrewmcgettigan.org/

Meiksins-Wood, Ellen. 1997. Back to Marx. Monthly Review 49 (2): 1-9.

MIT Media Lab. 2012. Affective Computing. Accessed April 1, 2012. http://affect.media.mit.edu/

MIT. 2012. 10x Human-Machine Superperformance. Accessed April 1, 2012. http://10x.media.mit.edu/

Neary, Mike, and Andy Hagyard. 2010. Pedagogy of Excess - an Alternative Political Economy of Student Life. In The Marketisation of Higher Education: The Student as Consumer, edited by Mike Molesworth, Richard Scullion and Elizabeth Nixon, 209-24. London: Routledge.

Negri, Antonio. 1989. The Politics of Subversion: A Manifesto for the Twenty First Century. Cambridge: Polity Press.

Neilsson, Brett, and Ned Rossiter. 2008. Precarity as a Political Concept, or, Fordism as Exception. Theory, Culture \& Society 25 (7-8): 51-72.

Newfield, Christopher. 2010. The Structure and Silence of Cognitariat. EduFactory Webjournal 0: 10-26. Accessed April 1, 2012. http://www.edu-factory.org/edu15/webjournal/n0/Newfield.pdf

Newfield, Christopher. 2012. Remaking the University. Accessed April 1, 2012. http://utotherescue.blogspot.com/

Noble, David F. 1998. Digital Diploma Mills: The Automation of Higher Education. First Monday 3 (1): Accessed April 1 , 2012. http://firstmonday.org/htbin/cgiwrap/bin/ojs/index.php/fm/article/view/569/490

Occupy Wiki. 2012. OccupyWiki.org. Accessed April 1, 2012. http://occupywiki.org/

OpenDemocracy. 2012. \#occupy communiques. Accessed April 1, 2012. http://www.opendemocracy.net/freeformtags/occupy-communiques

Postone, Moishe. 1996. Time, Labour and Social Domination: A Reinterpretation of Marx's Critical Theory. Cambridge: Cambridge University Press.

Postone, Moishe. 2009. Rethinking Marx's Critical Theory. In History and Heteronomy: Critical Essays (UTCP Booklet 12), edited Moishe Postone, Viren Murthy and Yasuo Kobayashi, 31-47. Tokyo: The University of Tokyo Center for Philoso- 
phy.

Porto Interactive Center. 2012. LifeisGame Project. Accessed April 1, 2012. http://www.portointeractivecenter.org/lifeisgame/

Really Open University. 2012. The Really Open University. Accessed April 1, 2012. http://reallyopenuniversity.wordpress.com/

Robinson, Peter, and Rana el Kaliouby. 2009. Computation of Emotions in Man and Machines. Philosophical Transactions of the Royal Society B: Biological Sciences 364 (1535): 3441-3447. doi:10.1098/rstb.2009.0198.

Roy, Deb. 2004. 10x: Human-Machine Symbiosis. BT Technology Journal 22 (4). Accessed April 1, 2012. http://10x.media.mit.edu/10x draft.pdf

Sanchati, Rupesh, and Gaurav Kulkarni. 2011. Cloud Computing in Digital and University Libraries. Global Journal of Computer Science and Technology 11 (12): 36-41. Accessed April 1, 2012. http://globaljournals.org/GJCST_Volume11/6Cloud-Computing-in-Digital-and-University.pdf

Short, Adrian. 2011. It's the End of the Web As We Know It. Accessed April 1, 2012. http://adrianshort.co.uk/2011/09/25/itsthe-end-of-the-web-as-we-know-it/

The Sociological Imagination. 2012. Radical Education Projects. Accessed April 1, 2012. http://sociologicalimagination.org/a-work-in-progress

Stahl, Bernd Carsten. 2004. E-Teaching - The Economic Threat to the Ethical Legitimacy of Education? In Journal of Information Systems Education 15 (2): 155-66.

Sykes, Jonathan, and Simon Brown. 2003. Affective gaming: measuring emotion through the gamepad. In $\mathrm{CHI}$ ' 03 extended abstracts on Human factors in computing systems, 732-733. Ft. Lauderdale, FL: ACM. doi:10.1145/765891.765957

Tao, Jianhua, and Tieniu Tan. 2005. Affective Computing: A Review. Lecture Notes in Computer Science 3784: 981-995.

The Think Trust. 2010. Cloud Computing Scenario. Accessed April 1, 2012. http://www.think-trust.eu/downloads/think-trustdocuments/cloud-computing_v0-2/download.html

Tiqqun. 2001. The Cybernetic Hypothesis. Accessed April 1, 2012. http://archive.org/details/Tiqqun1

Tronti, Mario. 1973. Social Capital. Telos 17: 98-121.

Valtysson, Bjarki. 2011. Facebook as a Digital Public Sphere: Processes of Colonization and Emancipation. tripleC - Cognition, Communication, Co-operation 10 (1): 77-91. Accessed April 1, 2012. http://www.triplec.at/index.php/tripleC/article/view/312

Vercellone, Carlo. 2007. From Formal Subsumption to General Intellect. Historical Materialism 15 (1): 13-36.

Virno, Paolo. 2001. General Intellect. Generation Online. Accessed April 1, 2012. http://www.generationonline.org/p/fpvirno10.htmVirno, Paolo. 2004. A Grammar of the Multitude: For an Analysis of Contemporary Forms of Life. Los Angeles: Semiotext.

Virno, Paolo. n.d. General Intellect, Exodus, Multitude: Interview with Paolo Virno. Archipélago (54). Accessed April 1, 2012. http://www.generation-online.org/p/fpvirno2.htm

Virno, Paolo, and Michael Hardt, eds. 1996. Radical Thought in Italy: A Potential Politics. Minneapolis: University of Minnesota Press.

Walden, Ian. 2011. Accessing Data in the Cloud: The Long Arm of the Law Enforcement Agency. Social Science Research Network. Accessed April 1, 2012. http://papers.ssrn.com/sol3/papers.cfm?abstract_id=1781067

Wake, Matthew, and Bernd Carsten Stahl. 2010. Ethical Issues of the Use of Second Life in Higher Education. In Proceedings of ETHICOMP, 13 to 16 April 2010, Tarragona, Spain.

Weber, Max. 1969. The Theory of Social and Economic Organization. New York: Macmillan.

Williams, Jeffrey, J. 2012. Deconstructing Academe: The birth of critical university studies. Accessed April 1, 2012. http://www.edu-factory.org/wp/deconstructing-academe-the-birth-of-critical-university-studies/

Winer, Dave. 2011. Facebook is scaring me. Accessed April 1, 2012. http://scripting.com/stories/2011/09/24/facebooklsScaringMe.html

xDelia. 2012. Xcellence in Decision-making through Enhanced Learning in Immersive Applications. Accessed April 1, 2012. http://www.xdelia.org

Zhou, Feng. Duh, Henry Been-Lirn, and Mark Billinghurst. 2008. Trends in Augmented Reality Tracking, Interaction and Display: A Review of Ten Years of ISMAR. In ISMAR '08: Proceedings of the 7th IEEE/ACM International Symposium on Mixed and Augmented Reality.

Žižek, Slavoj. 2009. First As Tragedy, Then As Farce. London: Verso.

\section{About the Authors}

Richard Hall

Dr Richard Hall is De Montfort University's Head of Enhancing Learning through Technology. He is a UK National Teaching Fellow and a Reader in Education and Technology. Richard is a Research Associate in the Centre for Computing and Social Responsibility at De Montfort University, and his research interests include: the idea of the University and radical alternatives to it; technology and critical social theory; resilient education and the place of co-operative practice in overcoming disruption in higher education; and the place of social media in the idea of the twenty-first century University. 
Bernd Stahl

Bernd Carsten Stahl is Professor of Critical Research in Technology and Director the Centre for Computing and Social Responsibility at De Montfort University, Leicester, UK. His interests cover philosophical issues arising from the intersections of business, technology, and information. This includes the ethics of ICT and critical approaches to information systems. 